\title{
Poverty Alleviation Strategies Through Sharia Microfinance Institutions Politico-Economics Study With Tawhidi Approach
}

\author{
Raden Heriyanto', Tatik Mariyanti ${ }^{2}$ \\ IEF Trisakti University ${ }^{1,2}$ \\ 1,2JI. Kyai Tapa No.1, RT.6/RW.16, Tomang, Kec. Grogol petamburan, Kota Jakarta Barat, \\ Daerah Khusus Ibukota Jakarta 11440 \\ e-mail: rheriyanto@gmail.com ${ }^{1}$, tatik m2002@yahoo.com²
}

To cite this document :

Heriyanto, R., \& Mariyanti, T. (2022). Poverty Alleviation Strategies Through Sharia Microfinance Institutions Politico-Economics Study With Tawhidi Approach. Aptisi Transactions on Management (ATM), 6(2), 132-141.

DOI :

https://doi.org/10.33050/atm.v6i2.1794

Abstract
This research aims to formulate a poverty alleviation strategy in Indonesia by empowering Islamic Microfinance Institutions (IMFI) based on political-economic studies. The Indonesian political-economic system is stipulated in Article 33 of the 1945 Constitution and its Explanatory Paragraph, making the people the center of attention for national economic development. The research uses the Analytic Network Process (ANP) method developed by Saaty. The ANP construction uses a model consisting of 3 main clusters, namely Problems, Solutions, and Strategies. The qualitative-quantitative assessment data is determined based on the Saaty Scale obtained through an in-depth interview of 9 expert respondents and practitioners in Islamic economics and finance. The results show that poverty alleviation strategies need to be carried out through cultural and structural approaches. The cultural approach includes revitalizing the concept of the people's economy as stated in the 1945 Constitution, campaigning for using the domestic product, socialization to increase literacy about waqf and zakat, improving the practices of bureaucratic ethics, and strengthening the values of togetherness and anti-monopoly. The strategy at structural approach is carried out by implementing policies to enhance the role of cooperatives in the national economy; increasing the education budget for the poor and needy; increased coordination between authorities; bureaucratic reform; and honest and fair law enforcement against corruption. For the micro-level at the LKMS institution, the cultural approach is carried out by strengthening literacy on Islamic financial instruments, increasing financial inclusion programs, social inclusion programs, and strengthening methods for obtaining funding sources from Islamic financial instruments. On the structural side, it is necessary to improve the professionalism and capability of supporting LKMS, institutional strengthening, internal control and supervision system, improvement of supporting infrastructure, and enhancing service convenience.

Keywords: Poverty Alleviation, Sharia Microfinance Institutions, Financial Inclusion Programme, Corporate Endowments, National Movement for the Use of Domestic Products. 


\section{Introduction}

Poverty is a common problem faced by developing countries in the world, including Indonesia. The Indonesian government continues to strive to overcome the problem of poverty for its citizens. Poverty alleviation has been a commitment from the government since the New Order government's to the current government.

The successful performance of poverty reduction in Indonesia can be seen from the graph below.

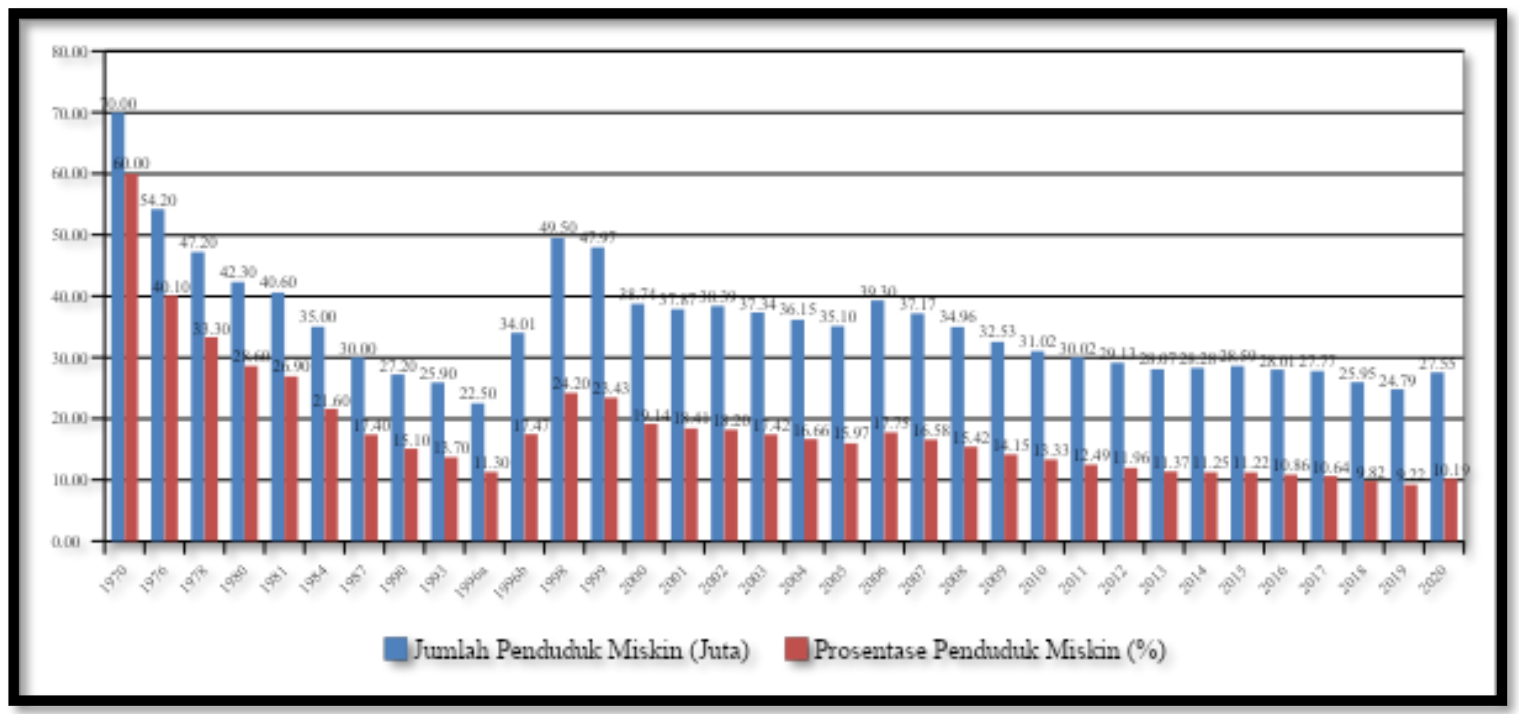

Diagram 1: Number and Percentage of Poor Population 1970 - 2020

\section{General Conditions of Poverty in Indonesia}

Based on the BPS Report as of September 2020, the poor numbered 27.5 million or $10.19 \%$ of the total population in Indonesia. Poverty profile by province, of the 27.55 million poor people in Indonesia, there are three provinces with the most significant number of poor people, namely East Java (4.58 million), Central Java (4.119 million), West Java (4.188 million). The Poverty Line in September 2020 was recorded at Rp458,947/capita/month with the composition of the Food Poverty Line of Rp339,004,- (73.87 percent) and the Non-Food Poverty Line of Rp119,943,- (26.13 percent). On average, poor households in Indonesia have 4.83 household members; so that the Poverty Line per poor household on average is IDR 2,216,714,-/poor household/month. (BPS Indonesia, 2021). [1]

Provinces with the most significant percentage of poor people are in Papua, West Papua, East Nusa Tenggara (NTT), and Maluku. The rate of poor people in Papua was 26.80 percent in September 2020 or 912,230 people in the poor category. The Poverty Line in Papua is IDR 580,463 . The poor population in West Papua in September 2020 amounted to 215.22 thousand people (21.70 percent), with the percentage of the urban poor at $6.31 \%$ and the rural poor at $33.2 \%$. The Poverty Line as of September 2020 is IDR 616,387 per capita per month (BPS Provinsi Papua, 2021). The number of poor people in East Nusa Tenggara (NTT) Province in September 2020 was $1,173,530$ people, or $21.21 \%$ of the total population. The Maluku Poverty Line is IDR 573,685 per capita per month in September 2020 (BPS Maluku, 2021).[2]

\section{The Role of Cooperatives}

One of the elements of the political-economic system in Indonesia, as stated in the 1945 Constitution, is the existence of cooperative institutions as pillars of the economy. Cooperatives contributed $4.48 \%$ (451.95 trillion) of the National GDP in 2017, while the contribution of Cooperatives in 2015 was $4.41 \%$ and in 2016 was only $3.99 \%$. [3] When compared to other countries, this contribution is still minimal, and the Government is trying to continue to increase the role of cooperatives in the national economy. [4] 
Elli Rusliana, the message of Article 33 of the 1945 Constitution is not only to provide instructions on economic order, but it is clear that what is intended is a special economic system that is not a capitalistic economy (based on individualism) but an economic system based on togetherness and kinship principles.[5] The moral message contained in Article 33 of the 1945 Constitution is to position the people as central-substantial and the teaching of loving others.[6]

\section{Scope of Research and Formulation of the Problem}

The Indonesian Banking Development Institute and Bank Indonesia noted that in 2014, of the 56.4 million MSEs throughout Indonesia, only $30 \%$ could access financing. Around $60 \%$ $70 \%$ of the entire MSME sector did not have access to funding through banking. This data is combined with poverty data in Indonesia and the significant role of Micro and Small Enterprises in contributing to GDP (57\%) and the necessary contribution from microfinance institutions to bridge poverty access to banking to improve their welfare. In addition, Seibel and Agung, IMFI is still lagging when compared to conventional Microfinance Institutions. [7]

Peter Koveos and Dipinder Randhawa state that Microfinance Institutions are an ingenious initiative and have a significant impact on poverty alleviation. They gave an example of a microfinance institution in Indonesia, namely Bank Rakyat Indonesia - Village Unit. Proven to contribute to reducing poverty from $40 \%$ in the mid-seventies until the 1997 crisis to $11 \%$.[8]

The problem with the development of Islamic microfinance institutions faced from a political economy perspective is the distortion of the Political-Economy System, which is considered in practice away from the economic value that makes the people the main target of development. here are obstacles due to corrupt, collusion and nepotism practices and the influence of capitalism and liberalism due to globalization.

\subsection{Research Objectives}

This study aims to formulate a poverty alleviation strategy through the empowerment of Islamic Microfinance Institutions in Indonesia. This study uses the Tawhidi String Relations (TSR) approach, also known as Interaction, Integration, and Evolutionary Learning (IIELP), with all the ontological, epistemological, and phenomenological details. In the following, the details of the objectives of this research will be presented.

1. Identify the factors that cause poverty in Indonesia that are useful for determining strategies to overcome them.

2. Identify weaknesses in the practice of economic-political systems related to poverty reduction programs through IMFI which are used to design solutions and strategies.

3. Identify factors that hinder the development of IMFI for improvement in the context of poverty reduction.

4. Formulate strategies that must be carried out to reduce poverty in Indonesia. The expected strategy is a series of macro policies implemented by the Government and the development of Islamic Microfinance Institutions at the micro level which have a major role in alleviating poverty in Indonesia.

\subsection{Literature Review And Research Framework}

\section{Poverty Theory}

Schiller, Laderchi, Saith, and Stewart, show that the way we conceptualize and measure poverty fundamentally influences poverty reduction policies and programs. Over the years, different perspectives on poverty have influenced government welfare policies towards poverty reduction.

\section{Definition of Poverty}

Adam Smith defines poverty as "the inability to afford the necessities required by nature or habit". Hence Smith mixes absolute measures (needs required by nature) with aspects of relative measures (needs required by habit).

Joseph Rowntree, in the early 20th century distinguished between primary and secondary poverty; primary poverty as "insufficient income to meet the minimum requirements for the maintenance of mere physical efficiency" the United Nations (UN), poverty as a lack of income and productive resources to ensure sustainable livelihoods; its manifestations include hunger and malnutrition, limited access to education and other basic services, social discrimination and 
exclusion, and lack of participation in decision-making. The World Bank defines poverty as a lack of well-being as measured by a person's ability to meet basic needs.

\subsection{Research Methods And Design}

\section{Research Design}

This research was conducted with a qualitative approach through the identification and investigation of a poverty alleviation problem in the study of political economy. This study is designed to develop a theory of poverty alleviation based on political-economic studies using the Tawhidi String Relations methodology (TSR). [9]

As a tool to implement this TSR model, a qualitative method of the Analytic Network Process (ANP) is used. The choice of this tool is because structured ANP uses clusters with elements in each group, which can influence and provide feedback between them so that the ANP network will also be able to show similarities to the concept of Interaction, Integration, and Evolutionary Learning Process (IIELP) process, which perform circular-causation as required by Tawhidi String Relations (TSR) stated by Choudhury.[10]

\section{Research Variables and Operational Definitions}

The following describes the research variables and operational definitions of each research variable:

\section{Problems - General Conditions of the Poor}

1. Lack of Access to Financial Institutions: The poor still lack access to formal financial institutions. The poor are mostly unbankable.[11]

2. Not Having Sufficient Guarantee: The poor do not have sufficient guarantees to apply for financing to formal financial institutions. [12]

3. Lack of Financial Literacy: Financial literacy is a series of processes or activities to increase the knowledge, skills and confidence of consumers and the public so that they are able to manage their personal finances better. Most of the poor are still low on financial literacy.[13]

4. Low Educational Attainment: The poor generally have a low level of education, resulting in a lack of job opportunities or business orientation.[14]

\subsection{Research Significance}

This research is in line with the vision, mission, and strategy of the National Committee for Sharia Finance (KNKS) as stated in the 2019-2024 Indonesian Sharia Economic Masterplan, which is to realize "an independent, prosperous and civilized Indonesia by becoming the world's leading Islamic economic center." More specifically, it has immediate relevance to the Main Strategy in the Sharia Economic Masterplan, namely Strengthening Sharia Finance and Strengthening Micro, Small \& Medium Enterprises. Poverty alleviation through the empowerment of sharia microfinance institutions has contributed to the goal of creating an independent and prosperous Indonesia and the development of a sharia economy in Indonesia.

\section{Results and Discussion Poverty Alleviation Strategy}

Strategy is the result of the synthesis of ANP or circular causation in the concept of TSR (Tawhidi String Relations). Strategy is the result of the interrelationship between problem, solution, and strategy. The ANP for Strategy results illustrates that the Macro strategy's weight takes precedence over the Micro Strategy. Although the scores varied, all respondents agreed that macro policies in terms of poverty alleviation through IMFI were prioritized. Meanwhile, the Micro policy is the second priority.[15]

Macro policies that are prioritized from the results of the ANP process provide an interpretation that political economy policies from poverty alleviation problems are prioritized. This is in line with the construction of the idea that one of the causes of poverty is the distortion of the political economy. The macro strategy is the answer to improving economic policies related to poverty alleviation. [16]

In the Macro Strategy criteria, the agreement of all respondents that the main priority is the development of Corporate Waqf. A corporate waqf (business entity) is a legal business structure that stipulates a business as a separate entity from shareholders, where the shareholders are 
wakif with no expectation of dividends. However, profits from the company are utilized for the poor people's benefit. The selection of business entity waqf becomes the main priority of the research results in line with the development of waqf, which has excellent potential for Islamic financial instruments. It is hoped that the government will play a role in increasing the potential for the use of waqf in a business.[16]

\subsection{Poverty Problems}

The results of data processing through ANP SuperDecision show that the dominant factor influencing poverty reduction strategies through the development of IMFI in Indonesia is the problem of the general condition of the IMFI institution itself. As shown in Diagram 2 Research Problems, the General Condition of IMFI Institutions is the main criterion for the problem with a weighted value of 0.3772 . Furthermore, the Distortion of the Political Economic System becomes the second problem criterion with a weight value of 0.3391 . There is an aspect of the General Condition of the Poor in Indonesia, which is the third priority in the problem criteria weighting 0.2795.[17]

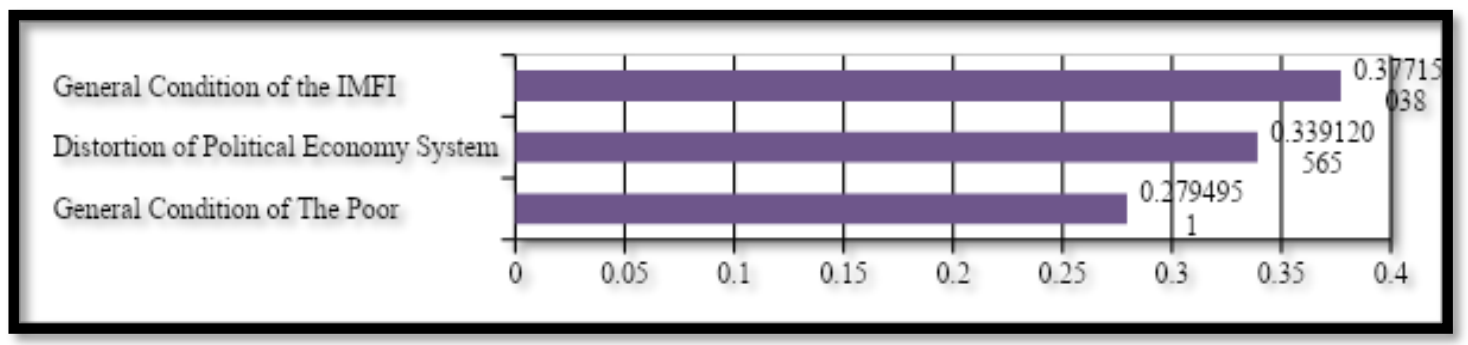

\section{Diagram 2: Prioritization of Research Problems}

If we look at the criteria general condition of the IMFI in more detail is caused by the main problem, namely that outreach is the main problem in poverty alleviation problems with a weight value of 0.2919 . The sub-criteria of Lack of Financing Sources is the second priority problem with a weight value of 0.2405 , followed by the Low-Quality Supporting Human Resources aspect with a weighted value of 0.2356 being the third priority problem and the element of Competition with Conventional MFIs being the last priority in poverty alleviation problems with a weight of 0.2274

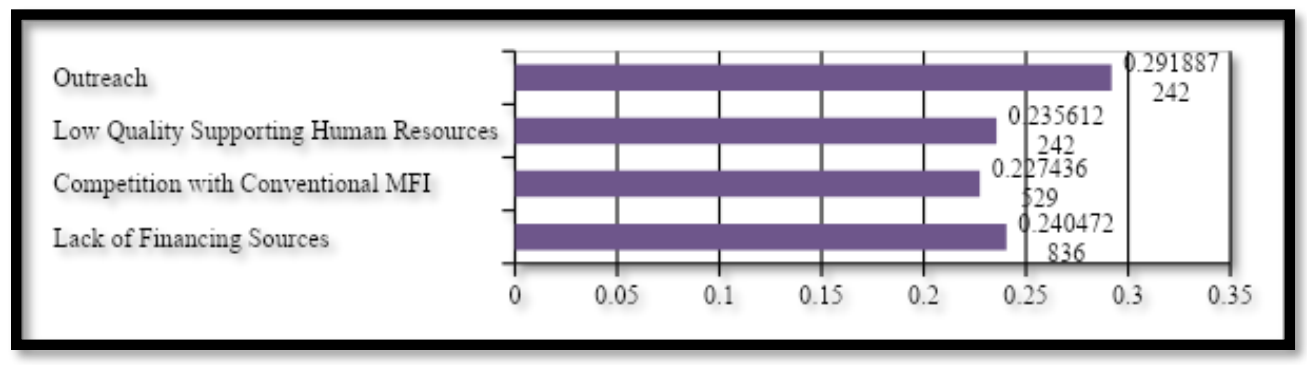

\section{Diagram 3: Prioritization of IMFI Development Problems}

For the Distortion of Political Economy System, the problem with the highest priority is the Suboptimal Role of Cooperatives in the Indonesian economy, which affects poverty reduction with a weight value of 0.2769 . Aspects of Bureaucratic Ethics and Integrity are the second priority problem with a weighted value of 0.2472 , followed by the Corruption Collusion Nepotism aspect with a weighted value of 0.2355 being the third priority issue, and the Influence of Capitalism and Liberalism aspects, being the last priority in the problem of poverty reduction with a weight value of 0.2283 . 


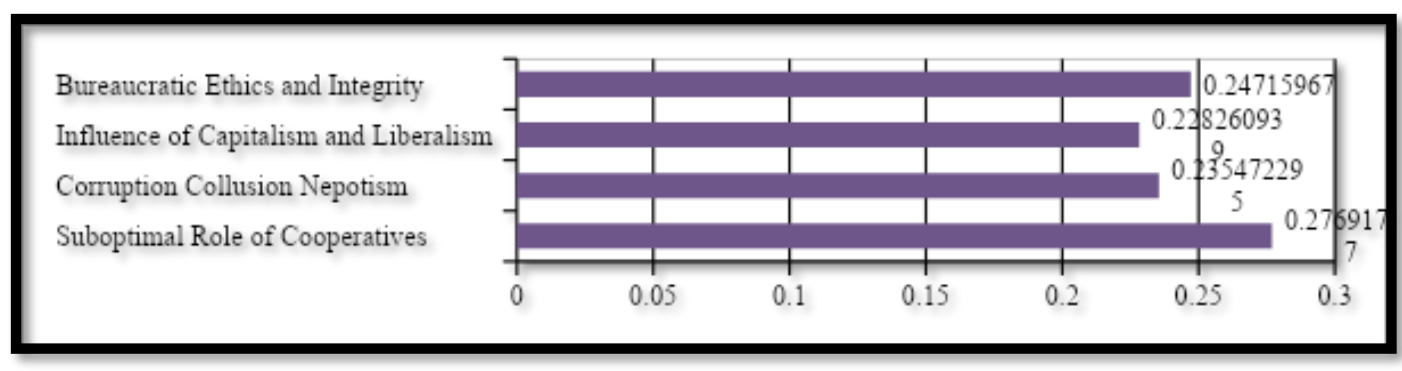

Diagram 4: Prioritization Political Economy Problems

Low educational attainment mainly influences the Conditions of the Poor's weight that affects poverty with a weighted value of 0.2763 . The Lack of Financial Literacy aspect is the second priority problem with a weighted value of 0.2680 , followed by the Lack of Access to Financial Institution's element with a weighted value of 0.2513 being the third priority problem, and the Not Having Sufficient Security aspect being the last priority in poverty reduction issues. with a weight value of 0.2029.[18]

Within the criteria distortion of the political-economic system, the highest weight that influences poverty reduction programs through IMFI is the role of cooperatives that have not been optimal in their contribution to the national economy. If you look at the economic system contained in the 1945 Constitution, Cooperatives should be the pillars of the economy in Indonesia. The correlation between cooperatives as the pillars of the national economy and poverty alleviation is the togetherness orientation of cooperative owners, namely cooperative members. Edi Swasono, the only business entity that can accommodate the economic activities of the poor or the poor is a cooperative. [19] The problem of ethical deficiency and bureaucratic integrity is in the second sub-criteria of the problem. This is related to the issue of ethical violations by state officials and the declining integrity of officials due to the many cases of corruption violations that are not covered by the law. Part of the bureaucratic problem is the regulation of IMFI policies which are still under the Ministry of Cooperatives and also under the regulation of the Financial Services Authority.[20] The next problem in the criteria for distortion of the political-economic system is the practice of corruption, collusion, and nepotism which undermines the foundations of the Indonesian economy. Inefficient economic practices affect the increase in prices of goods and services. The problem of the influence of globalization and economic practices that tend to be liberal is in fourth place in the problem of distortion of the political-economic system.[21] The national economy in the era of globalization cannot be separated from the influence of foreign economies by the arrival of foreign investors in the form of foreign investment and other business cooperation. The influence of foreign investment also has a role in the practice of the national economy so that the tendency of income distribution to shareholders is more pronounced than the togetherness of the nation in a cooperative format.[22]

The condition of the character of the poor that affects poverty sequentially is influenced by low educational attainment, lack of financial literacy, lack of access to financial institutions, and aspects of not having sufficient guarantees. The results of this study are in line with previous research, which found that the leading cause of poverty is the low educational attainment of the community. 


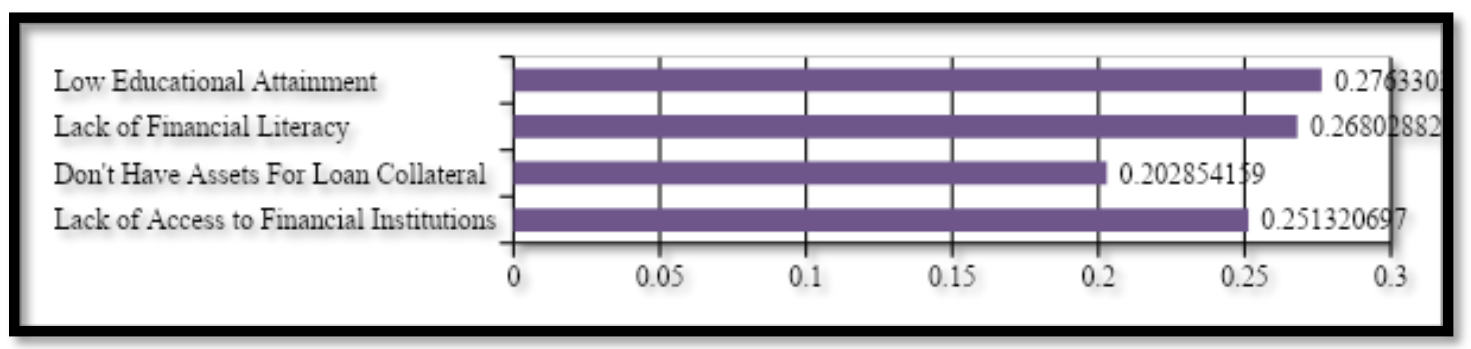

\section{Diagram 5: Prioritization The Poor Problems}

\subsection{Poverty Alleviation Strategy}

Strategy is the result of the synthesis of ANP or circular causation in the concept of TSR (Tawhidi String Relations). Strategy is the result of the interrelationship between problem, solution, and strategy. The ANP for Strategy results illustrates that the Macro strategy's weight takes precedence over the Micro Strategy. Although the scores varied, all respondents agreed that macro policies in terms of poverty alleviation through IMFI were prioritized. Meanwhile, the Micro policy is the second priority.[23]

Macro policies that are prioritized from the results of the ANP process provide an interpretation that political economy policies from poverty alleviation problems are prioritized. [24] This is in line with the construction of the idea that one of the causes of poverty is the distortion of the political economy. The macro strategy is the answer to improving economic policies related to poverty alleviation. [25]

In the Macro Strategy criteria, the agreement of all respondents that the main priority is the development of Corporate Waqf. A corporate waqf (business entity) is a legal business structure that stipulates a business as a separate entity from shareholders, where the shareholders are wakif with no expectation of dividends. However, profits from the company are utilized for the poor people's benefit. The selection of business entity waqf becomes the main priority of the research results in line with the development of waqf, which has excellent potential for Islamic financial instruments. It is hoped that the government will play a role in increasing the potential for the use of waqf in a business.[19]

\section{Conclusions And Recommendations}

Based on the research results, the following will discuss the causes of poverty in Indonesia associated with the IMFI development program.

1. Individual Deficiency

The general characteristics of the population that have a dominant influence on the occurrence of poverty in Indonesia in sequence are as follows:

a) The low educational attainment of the community so that the opportunity to earn a decent income is very minimal.

b) Lack of financial literacy, both knowledge of financial management, and all aspects of banking, credit and household financial information.

c) Lack of access to formal financial institutions, resulting in low opportunities to obtain capital loan assistance for production.

d) On average, the poor do not have assets for collateral, so it is difficult to obtain loans from formal financial institutions.[26]

2. Distortion of the political-economic system.

Regarding the distortions that occur in the practice of the political-economic system in Indonesia, the following are some of the factors that contribute to poverty in Indonesia:[27]

a) The role of cooperatives as the pillars of the national economy in Indonesia has not been optimal.

b) Lack of ethics and bureaucratic integrity. Bureaucratic ethics and integrity still face many challenges, including high levels of disciplinary violations and abuse of authority, not understanding and consistent implementation of laws and regulations, and ineffective control systems at various levels. Part of the 
bureaucratic problem is the regulation between authorities, especially the IMFI arrangements from the OJK and the Ministry of Cooperatives which are not yet harmonious.

c) The high practice of corruption, collusion and nepotism tends to hinder the poverty alleviation process.

d) Global capitalism and liberalism with the paradigm of freedom and competition also have a negative influence in realizing the ideals of economic development, namely justice for all Indonesian people. [28]

3. IMFI institutional conditions

From the institutional nature of the IMFI, the following are the factors that influence the institutional development program in the context of poverty alleviation.[29]

a) IMFI's reach is limited in big cities and has not yet reached the poverty area.

b) Lack of funding sources for IMFI operations. Sharia microfinance institutions are generally established with limited fund, because they are socially motivated and come from community groups so that their capital tends to be weak.

c) The quality of human resources supporting IMFI is still low.

d) Competition with Conventional MFIs.[30]

\subsection{Research Limitations}

This study only summarizes the answers and opinions of expert respondents in the field of Islamic economics and practitioners of microfinance institutions and is not followed by expert respondents from groups of politicians or government officials so that the possibility of opinions from different officials or politicians if included in this study could change the conclusions of the study.

\subsection{Recommendations For Further Research}

We suggest conducting research on the implementation of Corporate Waqf among the community to obtain data on the feasibility of establishing a waqf business entity. Corporate Waqf is a smart initiative and an ijtihad from the form of cash waqf into a productive joint waqf. Corporate Waqf is very relevant to the value of Pancasila, namely realizing social justice or general welfare for the wider community. On the other hand, the waqf property will remain and increase so that the range of results for mauquf alaih is getting wider day by day. 


\section{References}

[1] M. Z. A. BAKAR and S. A. BAKAR, "Prudent financial management practices among Malaysian youth: The moderating roles of financial education," J. Asian Financ. Econ. Bus., vol. 7, no. 6, pp. 525-535, 2020.

[2] V. Arumsari, M. R. Rizaldy, and P. S. Amalia, "Conceptualizing Zakat Institutions within the Framework of Hybrid Organizations," in International Conference of Zakat, 2020, pp. 97-106.

[3] E. Aspinall and W. Berenschot, Democracy for Sale: Pemilihan Umum, Klientelisme, dan Negara di Indonesia. Yayasan Pustaka Obor Indonesia, 2019.

[4] M. R. Rizaldy, V. Arumsari, and P. S. Amalia, "Does Blending Islamic Finance and Impact Investing Need A Specially Tailored Management Framework," Blending Islam. Financ. Impact Invest. SDGs. Jakarta, Fisc. Policy Agency, Minist. Financ. Repub. Indones., pp. 44-64, 2019.

[5] F. A. Rahman et al., "Pollution to solution: Capture and sequestration of carbon dioxide (CO2) and its utilization as a renewable energy source for a sustainable future," Renew. Sustain. Energy Rev., vol. 71, pp. 112-126, 2017.

[6] B. Bikbov et al., "Global, regional, and national burden of chronic kidney disease, 19902017: a systematic analysis for the Global Burden of Disease Study 2017," Lancet, vol. 395, no. 10225, pp. 709-733, 2020.

[7] S. A. A. Rohmayanti, "Kajian Literasi Keuangan Syariah terhadap Pemberdayaan Ekonomi Usaha Mikro Kecil dan Menengah Binaan Bank Indonesia Kantor Perwakilan Wilayah Jawa Timur." UIN Sunan Ampel Surabaya, 2020.

[8] A.-H. M. Bashir, "Reducing poverty and income inequalities: Current approaches and Islamic perspective," J. King Abdulaziz Univ. Islam. Econ., vol. 31, no. 1, 2018.

[9] S. Indonesia, "Analisis Hasil SE2016, Lanjutan Potensi Peningkatan Kinerja Usaha Mikro kecil." Badan Pusat Statistik. https://www. bps. go. id/publication/2019/03/05 ..., 2019.

[10] A. Suryahadi, R. Al Izzati, and D. Suryadarma, "Estimating the impact of covid-19 on poverty in Indonesia," Bull. Indones. Econ. Stud., vol. 56, no. 2, pp. 175-192, 2020.

[11] S. Nasrin, A. Baskaran, and R. Rasiah, "Microfinance and savings among the poor: evidence from Bangladesh microfinance sector," Qual. Quant., vol. 51, no. 4, pp. 14351448, 2017.

[12] K. Arora and A. S. Bist, "Artificial intelligence based drug discovery techniques for covid19 detection," Aptisi Trans. Technopreneursh., vol. 2, no. 2, pp. 120-126, 2020.

[13] A. S. Bein, Y. I. Graha, and A. P. Pangestu, "Pandawan Website Design Based Content Management System As Media E-commerce Transaction," Aptisi Trans. Technopreneursh., vol. 2, no. 1, pp. 87-97, 2020.

[14] A. K. Badri, J. Heikal, Y. A. Terah, and D. R. Nurjaman, "Decision-Making Techniques using LSTM on Antam Mining Shares before and during the COVID-19 Pandemic in Indonesia," APTISI Trans. Manag., vol. 6, no. 2, pp. 167-180, 2022.

[15] U. Rahardja, E. P. Harahap, and D. D. Christianto, "Pengaruh Teknologi Blockchain Terhadap Tingkat Keaslian ljazah," Technomedia J, vol. 4, no. 2, pp. 211-222, 2021.

[16] D. Apriani, A. Williams, U. Rahardja, A. Khoirunisa, and S. Avionita, "The Use of Science Technology In Islamic Practices and Rules In The Past Now and The Future," Int. J. Cyber IT Serv. Manag., vol. 1, no. 1, pp. 48-64, 2021.

[17] U. Rahardja, F. Andriyani, and T. Triyono, "Model Scheduling Optimization Workforce Management Marketing," Aptisi Trans. Manag., vol. 4, no. 2, pp. 92-100, 2020.

[18] H. Tarigan, J. H. Sinaga, and R. R. Rachmawati, "Dampak Pandemi Covid-19 terhadap Kemiskinan di Indonesia," Pus Sos Ekon dan Kebijak Pertan, vol. 3, pp. 457-479, 2020.

[19] U. Rahardja, A. N. Hidayanto, N. Lutfiani, D. A. Febiani, and Q. Aini, "Immutability of Distributed Hash Model on Blockchain Node Storage," Sci. J. Informatics, vol. 8, no. 1, pp. 137-143, 2021.

[20] Q. Aini, M. Yusup, N. P. L. Santoso, A. R. Ramdani, and U. Rahardja, "Digitalization Online Exam Cards in the Era of Disruption 5.0 using the DevOps Method," J. Educ. Sci. Technol., vol. 7, no. 1, pp. 67-75, 2021.

[21] C. Lukita, S. Suwandi, E. P. Harahap, U. Rahardja, and C. Nas, "Curriculum 4.0: adoption of industry era 4.0 as assessment of higher education quality," IJCCS 
(Indonesian J. Comput. Cybern. Syst., vol. 14, no. 3, pp. 297-308, 2020.

[22] D. N. Saputra, "Effort To Improve Elementary Students Interest On Music Subject With 'Learning By Doing' Method Class:(Case Studies of School Curriculum in Music Education)," ADI J. Recent Innov., vol. 2, no. 2, pp. 201-207, 2021.

[23] U. Rahardja, N. Lutfiani, S. Sudaryono, and R. Rochmawati, "The Strategy of Enhancing Employee Reward Using TOPSIS Method as a Decision Support System," IJCCS (Indonesian J. Comput. Cybern. Syst., vol. 14, no. 4, pp. 387-396, 2020.

[24] M. Mardiana, N. Lutfiani, and R. S. Saga, "The Online Sales Application Of Black And White Print Based On Yii Framework On Higher Education E-Commerce Website," Aptisi Trans. Technopreneursh., vol. 1, no. 2, pp. 118-127, 2019.

[25] U. Rahardja, Q. Aini, and A. Khoirunisa, "Effect of iDu (iLearning Education) on Lecturer Performance in the Lecture Process," Aptisi Trans. Manag., vol. 2, no. 2, pp. 140-148, 2018.

[26] D. Mohammed, N. Aisha, A. Himki, A. Dithi, and A. Y. Ardianto, "Blockchain Is Top Skill For 2020," Aptisi Trans. Technopreneursh., vol. 2, no. 2, pp. 180-185, 2020.

[27] U. Rahardja, Q. Aini, E. P. Harahap, and R. Raihan, "GOOD, BAD AND DARK BITCOIN: A Systematic Literature Review," Aptisi Trans. Technopreneursh., vol. 3, no. 2, pp. 1-5, 2021.

[28] I. Amsyar, E. Cristhopher, U. Rahardja, N. Lutfiani, and A. Rizky, "Application of Building Workers Services in Facing Industrial Revolution 4.0," Aptisi Trans. Technopreneursh., vol. 3, no. 1, pp. 32-41, 2021.

[29] Z. Fauziah, H. Latifah, U. Rahardja, N. Lutfiani, and A. Mardiansyah, "Designing Student Attendance Information Systems Web-Based," Aptisi Trans. Technopreneursh., vol. 3, no. 1, pp. 23-31, 2021.

[30] U. Rahardja, Q. Aini, F. Budiarty, M. Yusup, and A. Alwiyah, "Socio-economic impact of Blockchain utilization on Digital certificates," Aptisi Trans. Manag., vol. 5, no. 2, pp. 106$111,2021$. 